\section{Papiya Datta*}

Dr. Soumosish Paul

\title{
AMERLIORATIVE EFFECT OF CINNAMALDEHYDE AGAINST LEAD ACETATE INDUCED SPLENIC TOXICITY OF SWISS ALBINO MICE (MUS MUSCULUS)
}

Research Scholar, Post Graduate Department of Zoology, Vidyasagar College, Kolkata and Department of Zoology, The University of Burdwan, Burdwan, West Bengal, India *Corresponding Author

Assistant Professor, Department of Zoology, APC College, Kolkata, West Bengal, India.

\section{Prof. (Dr.) Gobinda Chandra Sadhukhan}

\author{
Prof. (Dr.) Nimai
} Chandra Saha
Professor of Zoology (Rtd.); Former Professor-Director of UGC- HRDC, Jadavpur University, Kolkata, West Bengal, India; Pin 700032

Hon'ble Vice-Chancellor, The University of Burdwan; Professor of Zoology, Fisheries and Ecotoxicology Research Laboratory, Vice Chancellor's Research Group; Department of Zoology; The University of Burdwan, Burdwan; West Bengal, India; Pin: 713104.

Professor of Zoology; Parasitology and Microbiology Research Laboratory; HOD, Department of Zoology; The University of Burdwan, Burdwan; West Bengal, India; Pin : 713104.

ABSTRACT Our mother India is full of various herbal plants with great medicinal importance. Cinnamaldehyde, an active component of Cinnamon, one of the widely used spice has antifungal, anti-microbial, antioxidative and many other properties. Our present study is aimed to investigate the ameliorative effect of Cinnamaldehyde upon the splenic toxicity induced by chronic lead exposure. For this lead acetate was applied on female Swiss albino mice (Mus musculus) continuously for 120 days. After treatment with lead, only selective dose of Cinnamaldehyde was applied on the mice for last 30 days. For observing the hazardous effects of this heavy metal and curative effect of Cinnamaldehyde, we explored various biological parameters like TBARS, GSH along with morphometric and histo-pathological analysis. Our observations clearly depicted the dose-dependent ill effects of this toxic heavy metal. Post-treatment of Cinnamaldehyde at a selective dose helped the tissue to get rid of this toxicity at certain level. All these findings disclosed the ameliorative effects of Cinnamaldehyde upon lead toxicity on spleen.

\section{KEYWORDS : Cinnamaldehyde, , Toxicity protection, Lead acetate ,Swiss Albino mice}

INTRODUCTION:

One of the toxic heavy metal, lead was used by us from very ancient time though it has a great hazardous impact on environment [1]. Globally lead concentration was increased by various sources like mining, painting, printing, smelting, jewellery, toys, crystal vessels etc. This metal is mainly exposed through the respiratory and gastrointestinal tracts [2]. Bloodstream could absorb approximately $30-40 \%$ of inhaled lead whereas absorption through gastrointestinal system varied depending on age and nutritional status [3], [2]. Though half-life of lead estimated about $20-30$ years, it was reported that this metal was stored for extended periods of time [2]. Lead was mainly stored in bones but soft tissue was also a storing site of this heavy metal. It was reported that about $80-95 \%$ of retained lead was stored in the bone in case of adult whereas $70 \%$ of it is stored in case of children. Thus, soft tissues were more affected in children [3],[2]. Other organs of the body like kidney, liver, brain, spleen was also affected by accumulation of this toxic metal [4]. Various complications like amyloidosis and corpuscular necrosis in kidney, peri-bronchitis in lungs were very common during lead poisoning [5]. Along with many systems lead also affected adversely on reticulo-endothelial system and spleen was aimed as one of the target organ of lead poisoning.

It was reported that one of the active components of cinnamon, cinnamaldehyde is with full of different properties like anti-diabetic [6], anti-inflammatory [7], anti-oxidant [8] and many others [9]. Against this background, our research work was carried out to investigate the protective effectiveness of this herbal component, the cinnamaldehyde on splenic toxicity induced by chronic lead exposure.
MATERIALS AND METHODS:

Female Swiss albino mice (Mus musculus) of 10-15 days old, weighing about $15-20 \mathrm{gm}$ were used in our present investigation. The animals were acclimatized under normal temperature $\left(22^{\circ} \mathrm{C} \pm 5^{\circ} \mathrm{C}\right)$ and 12 hours period of day and night in plastic cages. They were given to free access of standard diet and distilled water and kept in animal house of Vidyasagar College maintaining proper hygienic conditions for 120 days, following the recommended animal ethical guidelines.

The mice were divided randomly into six groups each with 6 individuals. Group A were with control mice where distilled water was given throughout the period of experiment. Group B mice were treated both with distilled water and Cinnamaldehyde [Cn] @ 20mg/kg b.w. for last 30 days continuously. Mice of Group C and Group D were administered with lead acetate @ 40mg/kg b.w. continuously for 90 days. Subsequently mice of group $E$ and group $F$ were exposed with lead @ 60mg/kg b.w. for 90 days. After 90 days mice of group D and F were treated with Cinnamaldehyde @ $20 \mathrm{mg} / \mathrm{kg}$ b.w. [Cn] doses continuously for 30 days whereas mice of Group $\mathrm{C}$ and $\mathrm{E}$ were treated with lead acetate for last 30 days. At the afternoon Both Cinnamaldehyde and lead were applied once daily through oral gavages.

Lastly after 120 days, at the time of sacrificing, each mouse was weighted and anesthetized with the help of chloroform. After sacrificing the spleen tissue was removed and weighted. Biochemical analysis was done by using the tissue with the help of standard protocol. For histological analysis a portion of tissue was cut into small pieces and fixed in Bouins solution 
following standard procedure of $\mathrm{H}$ and $\mathrm{E}$ staining.

\section{RESULT:}

Study of Tissue Morphometry:

Firstly, from the morphometric point of view, a significant increase of spleen weight with increased concentration of lead was evident. Figure 1. (a) clearly shows the images of the spleen tissues of different groups of animals. With the help of Figure 1. (b) the ratio of organ weight to body weight was measured which showed a significant increment according to the higher concentration of lead and the ratio was lowered by Cinnamaldehyde.

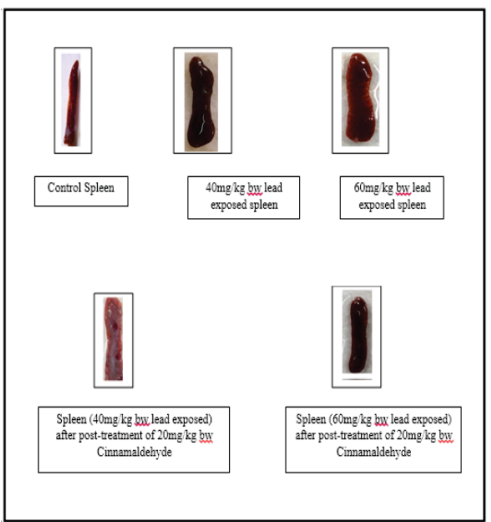

Fig: la. Morphological modifications of spleen in lead acetate exposed $(40 \mathrm{mg} / \mathrm{kg}$ bw and $60 \mathrm{mg} / \mathrm{kg} \mathrm{bw})$ and Cinnamaldehyde (20mg $/ \mathrm{kg} \mathrm{bw}$ ) post-treated sets of mice (Mus musculus).

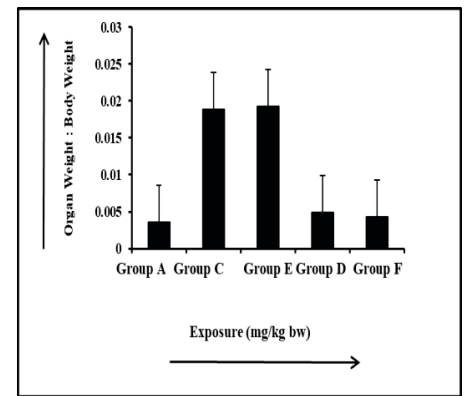

Fig: 1 b. Effect of Post-treatment of Cinnamaldehyde on organ weight and body weight ratio of different sets of mice (Mus musculus). Group A: Control group, Group C: $40 \mathrm{mg} / \mathrm{kg}$ bw lead exposed group, Group E: $60 \mathrm{mg} / \mathrm{kg}$ bw lead exposed group, Group D: Post-treated Cinnamaldehyde (20mg/kg bw) group, pre-treated with $40 \mathrm{mg} / \mathrm{kg}$ bw lead, Group F: Posttreated Cinnamaldehyde $(20 \mathrm{mg} / \mathrm{kg}$ bw) group, pre-treated with $60 \mathrm{mg} / \mathrm{kg}$ bw lead. Values are mean of 3 independent experiments with 5 animals in each group. $(p<0.005)$

\section{Biochemical Āssey:}

An important marker of lipid peroxidation is Thiobarbituric acid reactive substances (TBARS). The TBARS levels in control group(Group A) and control + Cinnamaldehyde treated group (Group B) were measured where the data revealed no significant variation between them (Fig :2.a).

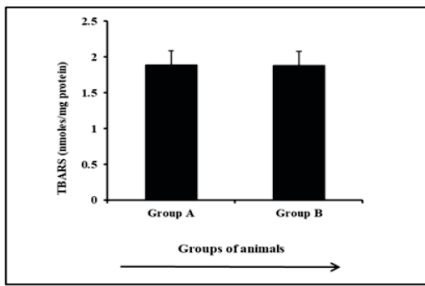

Fig: 2.a. Estimation of TBARS activity in Group A [Control] and Group B [Control + Cinnamaldehyde (20 mg/kg bw) cotreated] mice. Values are mean of 3 independent experiments with 5 animals in each group. $(p<0.005)$
TBARS of control group (Group A), lead acetate treated group (Group $C$ and E) and post treated group of Cinnamaldehyde (Group D and F) was measured. It was found that a significant enhancement of level in lead treated group whereas the level lowered towards the control level according to the graph. (Fig 2.b)

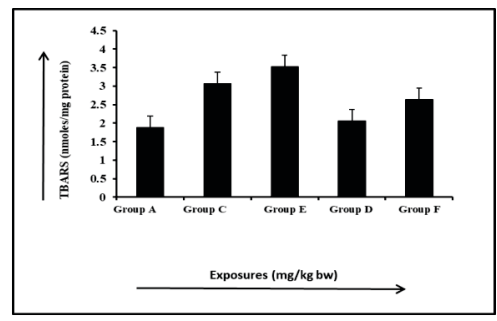

Fig: 2b. Graphical analysis of activity of TBARS in different sets of mice (Mus musculus). Group A: Control group, Group C: $40 \mathrm{mg} / \mathrm{kg}$ bw lead exposed group, Group E: $60 \mathrm{mg} / \mathrm{kg}$ bw lead exposed group, Group D: Post-treated Cinnamaldehyde (20mg/kg bw) group, pre-treated with $40 \mathrm{mg} / \mathrm{kg}$ bw lead, Group F: Post-treated Cinnamaldehyde ( $20 \mathrm{mg} / \mathrm{kg} \mathrm{bw}$ ) group, pre-treated with $60 \mathrm{mg} / \mathrm{kg}$ bw lead. Values are mean of 3 independent experiments with 5 animals in each group. $(\mathrm{p}<0.005)$

The ratio of reduced glutathione to oxidized glutathione is a measurement of cellular oxidative stress. According to our result, GSH level of control (Group A), different concentrations of Lead acetate exposed groups (Group $C$ and E) and post treated groups of Cinnamaldehyde (Group D and F)were shown by graph which clearly reveals that the level of GSH significantly decreased in lead exposed groups (Group C and $E$ )which was increased after post treatment of Cinnamaldehyde (Group D and F). (Figure 3)

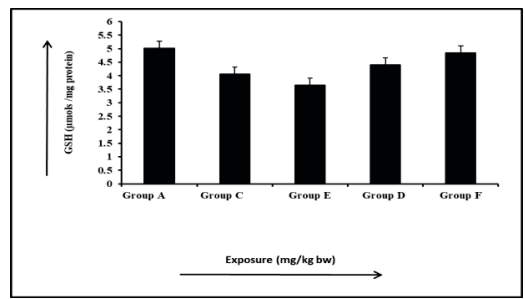

Fig:3 Graphical analysis of activity of GSH in different sets of mice (Mus musculus). Group A: Control group, Group C: 40 $\mathrm{mg} / \mathrm{kg}$ bw lead exposed group, Group E: $60 \mathrm{mg} / \mathrm{kg}$ bw lead exposed group, Group D: Post-treated Cinnamaldehyde $(20 \mathrm{mg} / \mathrm{kg} \mathrm{bw})$ group, pre-treated with $40 \mathrm{mg} / \mathrm{kg}$ bw lead, Group F: Post-treated Cinnamaldehyde ( $20 \mathrm{mg} / \mathrm{kg} \mathrm{bw}$ ) group, pre-treated with $60 \mathrm{mg} / \mathrm{kg}$ bw lead. Values are mean of 3 independent experiments with 5 animals in each group. $\mathrm{p}<0.005$

\section{Histological Analysis:}

$\mathrm{H} \& \mathrm{E}$ staining clearly showed the distorted structure of the spleen after exposure of lead in different concentrations. Congested red pulp was evident. Tissue necrosis was evident where white pulp of spleen was diffused into red pulp. Treatment with Cinnamaldehyde on those affected tissue showed a relative improvement when compared with control section. (Figure
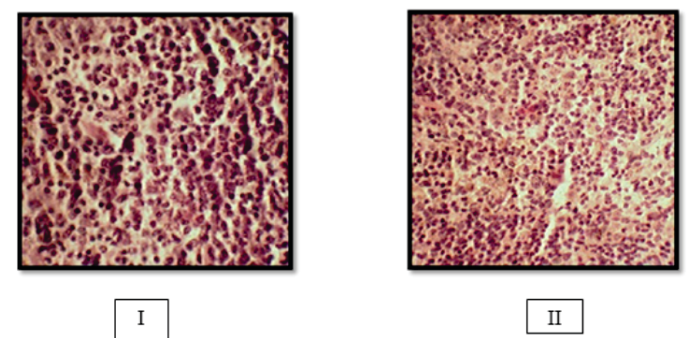


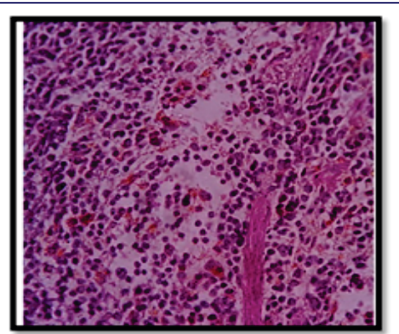

III

Fig 4: Histo-pathological Analysis of Spleen tissue from (I) Control Spleen (II) $60 \mathrm{mg} / \mathrm{kg}$ bw Lead exposed Spleen (III) Post-treated Cinnamaldehyde (20mg/kg bw) spleen, pretreated with $60 \mathrm{mg} / \mathrm{kg}$ bw lead (H\&E, magnification $\mathrm{x} 40$ ).

\section{DISCUSSION:}

One of the toxic persistent heavy metal lead is widely used in the environment. Lead poisoning is the ultimate outcome of the continuous use of this trace element. Herbal medicines were used frequently in our country from prehistoric age due to their cost-effectiveness, easy mode of availability and without any side effects.

In our present investigation, we want to study the efficacy of Cinnamldehyde, an active component of cinnamon, on spleen tissue after chronic lead exposure toxicity. During Morphometric analysis, it was found that introduction of lead in different concentrations, increased the sizes of spleen and cause splenomegaly. Cinnamaldehyde helped the tissue to regain its normal size.

Individual data of TBARS showed that Cinnamaldehyde itself had no toxic effects on spleen tissue. Data of TBARS of different lead exposed tissue clearly depicted that a prominent toxic effect was induced by this toxic metal which was reduced by post -treatment of Cinnamaldehyde $(20 \mathrm{mg} / \mathrm{kg} \mathrm{bw})$ towards its normal condition.

As the concentration of lead increased the level of GSH was decreased which clearly confirmed the emergence of stress due to lead toxicity. With the anti-oxidant property of Cinnamaldehyde the stress was reduced and the graph tended towards the control level.

In the histo-pathological tissue analysis, we found that Cinnamaldehyde had the highest efficacy to transform the spleen tissue into its original texture.

\section{CONCLUSION}

In this study it was clearly evident that Cinnamaldehyde played a protective role against chronic lead exposed splenic toxicity. Further studies will require to update its mode of action on lead toxicity.

\section{REFERENCES:}

1. Ghorbe F, Boujelbene M, Makni-Ayadi F, Guermazi F, Kammoun A, Murat JC, Croute F, Soleilhavoup JP, Feki AE . Effect of chronic lead exposure on kidney function in male and female rats: determination of a lead exposure biomarker. Archives of Physiology and Biochemistry .2001; 109(5): 457-463.

2. Patrick L. Lead Toxicity, a review of the literature. Part I: Exposure, Evaluation, and treatment. Alternative medicine review. 2006; 11(1).2-22.

3. Phillip AT, Gerson B. Lead poisoning - Part I: Incidence, Etiology, and Toxicokinetics. Clinics in laboratory medicine.1994; 14 (2):423-444.

4. Mudipalli A. Lead hepatotoxicity and potential health effects. Indian Journal of Medical Research.2007; 126(6): 518-527.

5. Muselin F, Trif AL, Brezovan DI, Stancu A, Snejana PE. The consequences of chronic exposure to lead on liver, spleen, lungs and kidney architectonics in rats. Lucrari Stiintifice Medicina Veterinara.2010; (2): 123-127.

6. Zhang W, Xu YC, Guo FJ, Ye M , Li ML. Anti-diabetic effects of cinnamaldehyde and berberine and their impacts on retinol-binding protein 4 expression in rats with type 2 diabetes mellitus. Chinese Medical Journal. 2008;(121): 2124-2128

7. Lee SC, Wang SY, Li CC, Liu CT.Anti-inflammatory effect of cinnamaldehyde and linalool from the leaf essential oil of Cinnamomum osmophloeum Kanehira in endotoxin-induced mice. Journal of Food and Drug Analysis. 2018; (26): 211-220.
8. Subash-Babu P, Alshatwi AA, Ignacimuthu S. Beneficial antioxidative and antiperoxidative effect of cinnamaldehyde protect streptozotocin-induced pancreatic -cells damage in wistar rats. Biomolecules \& Therapeutics. 2014 (22): 47-54.

9. Dorri M, Hashemitabar S, Hosseinzadeh. Cinnamon (Cinnamomum zeylanicum) as an antidote or a protective agent against natural or chemical toxicities: a review. Drug and Chemical Toxicology. 2018; (41): 338-351. 